\title{
ivili|copr
}

\section{Is the Unemployment Rate in Sweden Really 17 Percent?}

\author{
BY JOHN SCHMITT
}

In May 2006, the McKinsey Global Institute published a 252-page analysis of the Swedish economy. One of the report's most frequently cited findings was that the "de-facto" unemployment rate in Sweden in 2004 was between 15 and 17 percent, about three times higher than the official unemployment rate of 5.4 percent in that year (McKinsey Global Institute, 2006, Exhibit 6).

Important media outlets such as the Financial Times (September 10, 2006; January 22, 2007; April 17, 2007) and The Economist (September 9, 2006) repeated the McKinsey estimate as part of critiques of recent Swedish economic performance. The Economist even went so far as to accuse Sweden of being "a world champion at massaging its jobless figures."

To arrive at their 15-17 percent "de-facto" unemployment rate, McKinsey added what they viewed as "people who don't work, even though they should be able to" to the pool of the unemployed. These groups that McKinsey added to the unemployed included: "latent job candidates"; the "underemployed"; those "excluded from [the] labor force with ability to work"; and workers on government programs. Reasonable people could disagree with McKinsey concerning both their choices of the types and the numbers of individuals to include in their "de-facto" unemployment calculation. The analysis here, however, accepts that McKinsey methodology and, instead, asks: what happens if we use the same methodology to estimate the "de-facto" unemployment rate in the United States?

To calculate this, we added "discouraged workers," "marginally attached" workers, and part-timers for "economic reasons" (three official government categories), plus estimates of "early retirement" and the disabled population in the United States that could work following McKinsey's methodology, plus a reasonable estimate of the share of the U.S. workforce that are in moderately subsidized jobs (through the Earned Income Tax Credit).

John Schmitt is a senior economist at the Center for Economic and Policy Research. The author would like to thank Dean Baker for helpful comments, Rozina Ali for research assistance, and Ben Zipperer for analysis of the SIPP EITC data. 
Is the "Real" Unemployment Rate in the United States 15 Percent? • 2

The resulting "de-facto" unemployment rate in the United States is 13.8 percent, compared to a 5.5 percent official U.S. unemployment rate, and an estimated 15.5 percent "de-facto" Swedish unemployment rate.

If we also include the two countries' prison and jail populations in the "de-facto" unemployment rate --something in the spirit of the original McKinsey analysis, but not included in the original analysis done exclusively in the context of the Swedish economy-- the "de-facto" unemployment rate in the United States rises to 15.2 percent, just 0.5 percentage points lower than McKinsey's figure (15.7 percent) for Sweden including its prison and jail population.

The unemployment rate is far from a perfect measure of economic well-being or national labormarket performance. To the extent that critics of the Swedish economy rely on the McKinsey Global Institute's estimates of the "de-facto" unemployment in Sweden, those critics must also be sure to apply the same criteria to other countries serving as implicit or explicit points of comparison.

\section{Data and Methods}

The table summarizes our application of the McKinsey methodology for Sweden to the United States. The first two columns reproduce the McKinsey results for Sweden. The last two columns present corresponding figures from the United States, based on my analysis of a variety of U.S. data sources. The table follows the McKinsey methodology closely until panel (f), where, in the spirit of the McKinsey report, the table also considers the effect of prison and jail populations on the "defacto" unemployment rate, a factor not included in the McKinsey analysis. Since the McKinsey report covered 2004 for Sweden, the table looks at 2004 for the United States, as well, even though more recent data are also available.

For Sweden, the specific numbers in the table differ slightly from those published by McKinsey. The small discrepancy appears to be related to the way that McKinsey converted their estimates of the additional "de-facto" unemployed to a "de-facto" unemployment rate. Typically, the unemployment rate is calculated as the total number of unemployed divided by the total labor force, where the labor force is defined as the total employed plus the total unemployed. The McKinsey calculation appears to add the "de-facto" unemployed to the pool of unemployed in the numerator of the fraction used to calculate the unemployment rate, but to exclude the "de-facto" unemployed from the total "defacto" labor force in the denominator of the fraction. For consistency, and ease of comparison with the United States, we use the standard definition of the unemployment rate and apply it to both Sweden and the United States, using McKinsey's published numbers for the "de-facto" unemployed for Sweden and our own corresponding estimates for the United States.

\section{Official Unemployment Rate}

The first line in the table gives the official unemployment rate in both countries, following guidelines established by the International Labor Organization (ILO). According to this definition, a person is unemployed if: (1) they worked less than one hour in a nationally determined reference period (usually one week); (2) looked for worked during that period; and (3) were available to work during that period. By these definitions, in 2004, the unemployment rate in Sweden (5.3 percent) was basically identical to the unemployment rate in the United States (5.5 percent). 
TABLE 1

Comparison of unemployment rates in Sweden and the United States using the McKinsey Global Institute Methodology, 2004

\begin{tabular}{|c|c|c|c|c|}
\hline & \multicolumn{2}{|c|}{ Sweden } & \multicolumn{2}{|c|}{ United States } \\
\hline & Thousands & $\%$ labor force & Thousands & $\%$ labor force \\
\hline (a) Official unemployment & 235 & 5.3 & 8,149 & 5.5 \\
\hline (b) "Latent job candidates" & 140 & 3.1 & & \\
\hline Discouraged workers & & & 466 & 0.3 \\
\hline Marginally attached & & & 1,574 & 1.1 \\
\hline (c) "Underemployed" & 132 & 2.9 & & \\
\hline Part-time, economic reasons & & & 2,283 & 1.5 \\
\hline $\begin{array}{c}\text { (d) "Excluded from labor force } \\
\text { with ability to work" }\end{array}$ & 215 & 4.6 & & \\
\hline "Excess" disability & & & 3,561 & 2.4 \\
\hline "Excess" early retirement & & & 2,776 & 1.8 \\
\hline (e) Government programs & 106 & 2.3 & 5,421 & 3.5 \\
\hline Subtotal & 821 & 15.5 & 24,229 & 13.8 \\
\hline (f) Prison and jail & 7 & 0.2 & 2,136 & 1.4 \\
\hline Total & 828 & 15.7 & 26,365 & 15.2 \\
\hline Total labor force & 4,434 & 100.0 & 147,401 & 100.0 \\
\hline
\end{tabular}

Notes: Data for Sweden from McKinsey Global Institute, Sweden's Economic Performance: Recent Development, Current Priorities, May 2006, Exhibit 6. Figures here differ slightly from those in the McKinsey report due to rounding, and because we have adjusted the labor force in each calculation to include the implied increase due to each addition of "unemployed" workers. Data for U.S. are authors calculations; see text for complete sources and methods.

The U.S. unemployment rate is the official rate published by the Bureau of Labor Statistics (BLS) on its web page (http://www.bls.gov/).

\section{"Latent Job Candidates"}

The first category of "de-facto" unemployed workers that McKinsey adds to the Swedish unemployment rate are "latent job candidates," which McKinsey describes as "[p]ersons that are 
included in 'not in the labor force' but that want to work and can start within 14 days, including fulltime students who have applied for work." (McKinsey, Exhibit 6) McKinsey's estimate of 140,000 latent job candidates increases the "real" Swedish unemployment rate by 3.1 percentage points.

A roughly comparable group in the United States would include two categories of workers designated by the BLS: "discouraged workers" and the "marginally attached workers." The BLS defines discouraged workers as: "Persons not in the labor force who want and are available for a job and who have looked for work sometime in the past 12 months (or since the end of their last job if they held one within the past 12 months), but who are not currently looking because they believe there are no jobs available or there are none for which they would qualify." (See: http://www.bls.gov/bls/glossary.htm.) Marginally attached workers are: "Persons not in the labor force who want and are available for work, and who have looked for a job sometime in the prior 12 months (or since the end of their last job if they held one within the past 12 months), but were not counted as unemployed because they had not searched for work in the 4 weeks preceding the survey." (The discouraged worker category is a subset of the marginally attached.) In 2004, about 2 million people in the United States were either "marginally attached" or discouraged workers. Counting them as "de-facto" unemployed would raise the "real" unemployment rate 1.4 percentage points.

The U.S. data in the table are taken from the BLS website; they are derived from the 2004 Current Population Survey (CPS). The discouraged workers series is LNU05026645; marginally attached workers are series LNU05026642.

\section{Underemployed}

The second category of "de-facto" unemployed are the underemployed. For Sweden, McKinsey defined the group as "[p]ersons with employment but working less than they would like to" (McKinsey, Exhibit 3). By McKinsey's estimate, about 132,000 Swedish workers were underemployed in 2004, which would have raised the "de-facto" underemployment rate by 2.9 percentage points.

For the United States, the table shows the portion of part-time workers who say that they would like to work full-time but are not able to do so for "economic reasons" such as the unavailability of fulltime work or reduced demand for hours at their current employer. In 2004, about 4,566,000 U.S. workers reported working only part-time hours for economic reasons. Following McKinsey, the table multiplies this figure by half (because the part-time workers were, on average, only missing "half" a job). The inclusion of these involuntary part-time workers as "de-facto" unemployed would raise the unemployment rate 1.5 percentage points.

The involuntary part-time data are taken from the BLS web page (series LNS12032194).

\section{"Excluded from Labor Force with Ability to Work"}

McKinsey also includes as "de-facto" unemployed workers that it concludes have been excluded from the labor force but could, in fact, be working. This group is primarily "people who are on sick- 
leave or early retirement above and beyond the levels seen in around 1970" (McKinsey, p. 25). According to McKinsey's calculations, about 215,000 Swedes fall in this category. Including this group in the pool of the unemployed would raise the overall unemployment rate 4.6 percentage points.

For the United States, the table presents estimates of the size of corresponding groups in the United States. To calculate "excess disability," the table compares the share of the total population age 25 to 64 that received Social Security Disability Insurance (SSI DI) in 1970 (1.6 percent) with the share receiving SSI DI in 2004 (3.9 percent), and, following McKinsey, declares any SSI DI above the 1970 level as reflecting "excess" disability. Given the size of the population age 25 to 64 in 2004, the calculation implies that about 3,561,000 formally disabled workers would be "able to work," raising the "de-facto" unemployment rate 2.4 percentage points. (SSI DI data are taken from Autor and Duggan, 2006, Figure 1.)

To calculate "excess early retirement," the table takes a different approach. Instead of using the 1970 employment rate for 55 to 64 year olds as a benchmark, the table uses the 2004 employment rate for 55 to 64 year olds in Sweden. In 2004, despite McKinsey's concerns about excess early retirement in Sweden, the employment-to-population for 55 to 64 year olds (69.5 percent) was actually 9.6 percentage points higher in Sweden than it was in the United States (59.9 percent). The table, therefore, assumes that the United States in 2004 ought to be able to do at least as well as Sweden in 2004. McKinsey, of course, applies a stricter benchmark to Sweden, which was to do at least as well as Sweden around 1970, when employment rates for 55 to 64 year olds were higher than they were in 2004. Using contemporary Sweden as a benchmark, the McKinsey methodology applied to the United States suggests that the "de-facto" unemployment rate, including "excess early retirement", would be about 1.8 percentage points higher than the official rate that year. Using the employmentto-population rate in the United States in 1970 would have added only a negligible number of

workers to the "de facto" unemployment rate. (Employment-to-population rates for 55 to 64 year olds in Sweden and the United States are taken from the OECD, 2006, Tables C and D.)

\section{Government Programs}

McKinsey does not define exactly which workers it includes in "government programs," but presumably these involve government-provided or government-subsidized jobs. McKinsey estimates that about 106,000 Swedes fall in this category. Counting this group as "de-facto" unemployed would raise the unemployment rate 2.3 percentage points.

The United States also has a large program that subsidizes wages of many low-wage workers: the Earned Income Tax Credit (EITC). In 2004, about 21.6 million tax filing units, which may include more than one worker, reported receiving some income from the EITC (Brookings Institution, http://www.brookings.edu/metro/eitc.htm.) An analysis of data from the Survey of Income and Program Participation (SIPP) indicates that among one- and two-adult households receiving income from the EITC about 25 percent received EITC payments equal to more than 15 percent of their income from work. The table assumes that recipients in these fairly heavily subsidized jobs could reasonably be considered "de-facto" unemployed under the McKinsey criteria. Under these assumptions, the "de-facto" unemployment rate would increase 3.5 percentage points. 


\section{Prison and Jail Population}

The McKinsey report did not examine the effects of the prison and jail population on the "de-facto" unemployment rate in Sweden, presumably because it would have had only a negligible effect. In fact, when we use data from the International Center for Prison Studies on the Swedish prison population, under the assumption that all prisoners would count as "de-facto" unemployed, the impact would only be to raise the "real" unemployment rate 0.2 percentage points.

The U.S. prison and jail population, however, is much higher as a share of the population. Data from the same source put the comparable population in the United States in 2004 at about 2.1 million people. Including these prisoners as "de-facto" unemployed would raise the unemployment rate 1.4 percentage points.

For both Sweden and the United States, the prisoner populations are averages from the ICPS sixth and seventh reports on prison populations.

\section{Conclusion}

The McKinsey Global Institute's estimates of the "de-facto" unemployment rate in Sweden have received widespread attention, and have been used to put Sweden in an unfavorable light when compared to other economies. The problem is that McKinsey's calculations of Sweden's "official" and its "real" unemployment rates don't make similar adjustments to other -- implicit and explicit -comparison countries. If we apply the McKinsey methodology to the United States, the "de-facto" U.S. unemployment rate rises from about 5.5 percent to 13.8 percent (compared to 15.5 percent in Sweden). If we also include the prison and jail populations in both countries, the gap between Sweden and the United States is even smaller: 15.2 percent for the United States, compared to 15.7 percent for Sweden. If the McKinsey numbers are evidence that the Swedish economy needs significant reform and restructuring, then these figures for the United States also suggest an urgent need for reform and restructuring here. 


\section{References}

David Autor and Mark Duggan, "The Growth in the Social Security Disability Rolls: A Fiscal Crisis Unfolding," National Bureau of Economic Research Working Paper No. 12,436 August 2006.

Ibison, David. "Comment and Analysis: Model change: how Sweden is to shed its vast state holdings," Financial Times, January 22, 2007.

Ibison, David. "Sweden cuts taxes to boost employment," Financial Times, April 17, 2007.

International Center for Prison Studies. World Prison Population List. Sixth Edition.

International Center for Prison Studies. World Prison Population List. Seventh Edition.

McKinsey Global Institute. Sweden's Economic Performance: Recent Development, Current Priorities. May 2006. http://www.mckinsey.com/mgi/publications/sweden/

Munchau, Wolfgang. "The devaluation saga of Sweden's industrial rebirth," Financial Times, September 10, 2006.

Organization for Economic Cooperation and Development. OECD Employment Outlook 2006, Paris: OECD, July, 2006.

Unsigned. "Admire the best, forget the rest -- the Swedish Model," The Economist (U.S. edition), September 9, 2006. 